1840 's he is quoted as saying confidently, "If I miss it in one thing I will hit it in another." That confidence never left him, and, if it is possible for a person to will success, Gail Borden willed it, despite occasional infractions of the rules of good business.

Joe B. Frantz

HaRvard UNIVERSITY

\title{
The Society Announces Another Fellowship
}

Following the precedent it set last year by sponsoring the first Fellowship in Business History ever to be awarded, the Business Historical Society is announcing a similar Fellowship for the academic year 1949-50. The Fellowship carries a stipend of $\$ 2,500$ and enables an advanced student to spend a twelve-month period of research and study at the Harvard Graduate School of Business Administration.

The Society's interest in the Fellowship arose out of its desire to see courses in Business History more widely offered in college curricula. Since the field of Business History requires a fusion of two quite separate disciplines-history and business-training in the subject has been difficult to acquire. Until the establishment of the Fellowship last year, there was no formal means by which scholars in one field could become acquainted with the subject matter in the other; hence, only a few schools have been able to offer the course to their students.

The Fellowship encourages men holding their doctor's degrees in the field of history to spend a year at Harvard acquiring a familiarity with business. It gives them an opportunity both to attend courses and to do research on case histories.

Applications must be submitted by March 1, 1949. Inquiries and requests for application blanks should be directed to the Executive Secretary of the Society, 217 Baker Library, Boston 63, Massachusetts. 